\title{
THE METHOD OF DESTRUCTIVE SCENARIO FORECASTING FOR THE DEVELOPMENT OF DIVERGENT THINKING OF MANAGERS
}

\author{
Dr. Rezanovich Irina, South Ural State University (national research university), Chelyabinsk, Russian \\ Federation, E-mail: rezanovichiv@susu.ru \\ Dr. Rezanovich Anatoly, South Ural State University (national research university), Chelyabinsk, Russian \\ Federation, E-mail: rezanovichae@susu.ru \\ Dr. Piatkova Marina, South Ural State University (national research university), Chelyabinsk, Russian \\ Federation, E-mail: piatkovamr@susu.ru \\ Dr. Peredrienko Tatiana, South Ural State University (national research university), Chelyabinsk, Russian \\ Federation, E-mail: peredrienkoti@susu.ru
}

\section{A R T I C L E I N F O \\ Original Research \\ Received: November, 14.2019. \\ Revised: February, 20.2020. \\ Accepted: March, 03.2020. \\ doi: 10.5937/IJCRSEE2001061R \\ UDK \\ 005.32:159.955.075(470)}

Keywords:

education,

manager,

divergent thinking,

scenario forecasting,

method of destructive scenario,

forecasting.

\begin{abstract}
A B S T R A C T
The phenomenon of thinking is well studied in psychology, and many of its types are revealed. However, little attention is paid to the development of divergent thinking in general and the development of divergent thinking of managers in particular. At the same time, multidirectional management decisions, their prompt adoption and the originality of content are very necessary for enterprises. The aim of the article is to give the characteristic of divergent thinking, to note its features and to present own definition of the concept "divergent thinking of managers". In the article the analysis of one of the functions of managers, that is forecasting, is described. The scenario method and a new method of destructive scenario forecasting are proposed. The algorithm of the last method application in the form of a technological map is shown. The result of using the method for 2 years on specialized programs of professional development and retraining of managers is described. The results of mathematical processing of the obtained data on diagnostic procedures are presented. They testify that in the experimental groups the development of qualitative characteristics of divergent thinking of managers proceeded more intensively than in the control ones, in which the method of destructive scenario forecasting was not used. That proves the effectiveness of the proposed method for the development of divergent thinking of managers.
\end{abstract}

(C) 2020 IJCRSEE. All rights reserved.

\section{INTRODUCTION}

Currently, large-scale political and social transformation, continuous economic reforms and competition of businesses caused the emergence of a large number of non-standard management situations. The existing challenges have raised the complexity and number of management tasks, which significantly increased the responsibility of managers for the accuracy, timeliness and

\section{Corresponding Author}

Dr. Peredrienko Tatiana, South Ural State University (national research university), Chelyabinsk, Russian Federation, E-mail: peredrienkoti@susu.ru

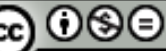

This work is licensed under a Creative Commons Attribution - NonCommercial - NoDerivs 4.0. The article is published with Open Access at www.ijcrsee.com efficiency of decisions.

The enlargement in non-standard situations and the growth of new management tasks required constant updating of knowledge and skills of managers. Probably that is why seminars, round tables, master classes and, of course, more large-scale specialized MBA (Master of Business Administration) and Executive MBA programs have become so popular today.

These two programs appeared in America at the beginning of the twentieth century and have become very popular both throughout the world and in Russia. The MBA program provides for the knowledge and develops the skills of those who do not have an economic or managerial education, or the education was received long ago and it needs to be updated.

The Executive MBA program is 
designed for business owners, managers and top managers of enterprises. Trainees, as a rule, have significant leadership experience. While studying they work out various aspects of the business in the system, improve their skills in making non-standard, but wellgrounded managerial decisions, and acquire new connections and contacts.

A modern manager is required to analyze the current situation, to consider various solutions, to predict the possible results of his actions and after that make informed management decisions. In this case, not only the knowledge and skills of a manager should be updated, but also his thinking should be improved. It should become more flexible, dynamic, creative, and at the same time systematic, critical and rational. These thinking qualities can be developed at any age, as evidenced by the studies of Riegel, 1976; Ananiev, 2001, Dweck, 2006 and other scientists.

The new management tasks, the need to develop mental abilities led to the search of the pedagogical community of relevant trends, technologies, methods and means of professional development for managers. One of these trends is the development of divergent thinking of a manager, which determines the ability to find solutions to management problems.

\section{MATERIALS AND METHODS}

The phenomenon of thinking is actively studied by psychologists and it is evidenced by a large number of scientific theories. In the following researches this phenomenon is considered from different perspectives: thinking as behavior (Wertsch, 1998 and other); thinking as an information processing system (Lindsay et al., 2001; Neisser, 2004 and other); thinking as a motivational process (Maslow, 1967 and other); thinking as an intellectual function (Brushlinsky and Tikhomirov, 2013 and others); thinking as a structural rearrangement of operations (Wertheimer, 1945); thinking as an association of representations (Mill, 2020 and others) etc.

The studies of most psychologists prove that thinking appears in a problem situation, the solution of which occurs due to the transformation of certain open relationships. In the course of this transformation such operations as: analysis, synthesis, abstraction, generalization are used. Some previously hidden relationships are revealed, which lead to the solution of problems.

There is no consensus on the types of thinking among scientists. Therefore, various classifications are offered: visualeffective, visual-figurative, abstract-logical and verballogical; theoretical and practical; discursive and intuitive; productive and reproductive, etc. In psychology, there are studies of some specific types of thinking: engineering thinking (Lucas and Hanson, 2016); visual thinking (Arnheim, 2001); dialectical thinking (Riegel, 1976; Veraksa, 2019); fixed thinking and growth thinking (Dweck, 2006); creative thinking (Lindsay et al., 2001; Katrenko et al., 2018); critical thinking (Bailey et al., 2019). The above list of types of thinking is not complete. There are convergent and divergent types which are less presented in the scientific literature.

Convergent thinking is a linear, invariant thinking, which is characterized by clear direct links between phenomena and algorithmized thought. Such thinking complicates the adequacy of the perception of events, reduces the efficiency of work with the team and prevents the understanding of situational problems.

Divergent thinking is a multidirectional search for multiple answers to one question. Such thinking is characterized by the absence of rigid links and dependencies between phenomena. The concept of "divergence" is borrowed from the natural sciences, its authors are considered to be Darwin, Ch. (1998) and Wallace, A. (2013). Both scientists explained by this concept the diversity of biological species of animals and plants.

The definition of divergent thinking was given by Guilford, J. (1967) to characterize multidirectional thinking, in other words, thinking that deviates from the stereotype. The scientist called the main qualities of divergent thinking: fluency, flexibility, originality and accuracy. In this context, the quality of thinking meant the following:

- fluency - the ability to express the maximum number of ideas in a certain time interval;

- flexibility - the ability to generate new non-standard ideas;

- originality - the ability to put forward non-obvious ideas, which can not coincide with the generally accepted ideas;

- accuracy - the ability to give a complete view of their thoughts and reasoning.

The study of divergent thinking was continued by Piaget, J. (1977). He considers it as a form of independent thinking and 
independent actions determined by education and personal life experience.

Many scientists revealed the peculiarities of divergent thinking and factors of its development. So the following specific features of this type of thinking were formulated: inner freedom, a manifestation of the ability to the evaluation, comparison, analysis, hypothesis-building; perception of fluency and flexibility (Guildford, 1967, Piaget, 1977); the leading role in the creative process (Acar and Runco, 2015); versatility (Matyushkina, 2018); research activity (Schneder, 2007); the interaction of different forms of thinking in solving creative problems (Lee and Therriault, 2013); the presence of a creative mental field (Dorfman, 2015).

Based on the existing ideas of scientists about divergence and divergent thinking, we propose to consider divergent thinking of managers as a special kind of thinking that allows to generate quickly various management decisions in non-standard situations, taking into account a variety of external and internal factors affecting the event. At the same time, we believe that each management decision should be characterized by a certain independence which can be private and even isolated. In this case, divergent ideas can be presented in the form of a "cognitive market", with inherent diversity and choice. To say more, these multi-vector possibilities, creating uncertainty and variability, ensure that managers take extraordinary management decisions.

\subsection{Method of destructive scenario forecasting}

Many modern economists are convinced that in the conditions of the market managers have to regulate economic activity of an enterprise and, respectively, to be capable to foresee and predict consequences of the made decisions. Forecasting is a kind of prediction how a situation in the future time is constructed. Forecasting concerns probable or desired events, phenomena, aspects, states and problems of the future. The main purpose of forecasting is to determine the connection of events, phenomena or factors affecting the development and change of the system or processes.

There are various methods of forecasting, which are quite successfully used in management. One of them is a scenario, which is used to study the possible trends and the likely consequences of certain management decisions in order to choose the best option. The scenario is a hypothetical picture of the development of certain events in time and space. Therefore, the use of a forecast scenario in management allows a manager to anticipate the consequences of the choice of a management decision and to generate the content and objectives of decisions in order to reduce or eliminate critical situations.

When using the scenario forecasting method, three scenarios are often drawn up: optimistic, pessimistic and realistic. The effectiveness of this method of forecasting proved James, M. and Koller, T. (2000) using it to evaluate 11 Brazilian companies. They noted that the scenario forecasting gives the closest result to the real market situation. Usually three main types of the final scenario are distinguished: scenario-essay, analytical and formalized scenario and each of them is developed for positive tasks. For example, when new products enter the market a scenario is developed to answer the questions: What demand can be for new products? How does advertising affect consumers? How will competitors react? etc.

This approach is traditional and, therefore, the development of scenarios is also carried out traditionally according to the past experience. But it's not always correct. In addition, managers who participate in the development of scenarios often perceive them as routine work and do not seek to be creative. This fact we observed annually, conducting classes on various programs of professional development and retraining of managers. At the same time, students are actively using scenario forecasting, many even call it a "favorite method".

This situation caused the modernization of the project-based learning. And we decided to take into account the fact that creating something is always difficult but destroying is always easy and even funny. So we reformulated the tasks transforming creative to destructive ones. Some examples of such transformations are presented in the Table 1. 
Table 1. Examples of task transformation from creative to destructive

\begin{tabular}{|c|c|}
\hline Creative tasks & Destructive tasks \\
\hline $\begin{array}{l}\text { What should be done to } \\
\text { increase sales by } 5 \% \text { in a } \\
\text { company? }\end{array}$ & $\begin{array}{l}\text { What should be done } \\
\text { not to increase sales in a } \\
\text { company? }\end{array}$ \\
\hline $\begin{array}{l}\text { What should be done to } \\
\text { increase the } \\
\text { competitiveness of a } \\
\text { company? }\end{array}$ & $\begin{array}{l}\text { What should be done to } \\
\text { reduce the } \\
\text { competitiveness of the } \\
\text { company or to destroy } \\
\text { it? }\end{array}$ \\
\hline $\begin{array}{l}\text { How can the product } \\
\text { quality be improved? }\end{array}$ & $\begin{array}{l}\text { How can the product } \\
\text { quality be reduced? }\end{array}$ \\
\hline $\begin{array}{l}\text { What should be done to } \\
\text { increase productivity? }\end{array}$ & $\begin{array}{l}\text { What should be done to } \\
\text { reduce productivity? }\end{array}$ \\
\hline $\begin{array}{l}\text { What can be done to } \\
\text { improve the efficiency } \\
\text { of management in the } \\
\text { company? }\end{array}$ & $\begin{array}{l}\text { What can be done to } \\
\text { reduce the effectiveness } \\
\text { of management in the } \\
\text { company? }\end{array}$ \\
\hline $\begin{array}{l}\text { What should be done to } \\
\text { increase the return on } \\
\text { assets? }\end{array}$ & $\begin{array}{l}\text { What should be done to } \\
\text { reduce the return on } \\
\text { assets? }\end{array}$ \\
\hline $\begin{array}{l}\text { How can we speed up } \\
\text { the launch of a new } \\
\text { product? }\end{array}$ & $\begin{array}{l}\text { How can we slow down } \\
\text { the launch of a new } \\
\text { product? }\end{array}$ \\
\hline $\begin{array}{l}\text { What should be done to } \\
\text { increase staff } \\
\text { motivation? }\end{array}$ & $\begin{array}{l}\text { What should be done to } \\
\text { reduce staff motivation? }\end{array}$ \\
\hline
\end{tabular}

In this case, we partially use the method of preventive forecasting as an attempt to predict the possible actions of something or someone on the basis of the available incomplete data. But let us emphasize that we use destructive tasks or, as we sometimes call "crash tasks". Having received a destructive scenario, it is not difficult for managers to implement the reverse, in other words, all the ideas are put forward to replace the opposite. This task also is taken very enthusiastically, and managers are very surprised by the result, which makes them happy.

The method of destructive scenario forecasting can be presented as the algorithm.

1) Managers are offered a situation (or they offer it themselves). This can be a specially designed case or a real situation that occurs at one of the enterprises. The information is taken from the public records, or one of the listeners became a participant and is able to provide an objective description of the events;

2) Mini-groups are created, the formation principle of which is not important (co-workers, in sympathy with each other, in the location in the classroom, etc.). They are working on one task. For a change, you can offer groups be divided: by the level of management (initial, average, high); by institutions of influence (competitors, public organization, partners, government agencies, etc.); by possible structural units of an enterprise.

3) Groups are given a goal formulated in a destructive, negative context;

4) Firstly the ideas are generated without discussion. There should be $10-15$ ideas. Then these ideas are discussed, classified on various grounds. For example they can be grouped according to effect achievement: economic, social, psychological. The most promising proposals are selected based on the goal;

5) Next, there is the second discussion, as a result of which some ideas are removed from the list. That is the ones "which can be abandoned". Thus, the most interesting and effective offers remain;

6) The received list of proposals destroying an enterprise is considered from the position of opposition. That is how to reduce or eliminate these threats.

7) The groups get a list of solutions that are fully consistent with the positive, creative ideas of improving the functioning or development of an enterprise.

It might seem that this method is more time-consuming than the simple scenario method. However, our application of it shows that the time difference is very small. But the quality of the ideas received with the help of the described method is much higher.

\section{RESULTS}

To confirm our assumption about the effectiveness of the method of destructive scenario forecasting, we conducted the research work. One hundred fifty-two managers studied at various programs at South-Ural State University in 2017-2019 took part in the experiment. Seventy-seven managers were in three experimental groups, and 75 managers in three control groups. The number of people in the groups is sufficient, as it can ensure the reliability of the results at the level of statistical significance $\alpha=0,95$.

The method developed by us was used in the experimental groups, the traditional scenario forecasting method was used in the control groups. We carried out the comparison according to several parameters: the number of ideas and their originality, dynamics of work, activity of students and their satisfaction. The method of observation, timing, performance analysis and questionnaires were used for 
assessment. According to the results the number of ideas and the dynamics of their generation increased, also the activity of participants improved. There were almost no cases of students' evasion from the work and their satisfaction with classes was noted.

Therefore, the proposed method of destructive scenario forecasting is quite effective. But our aim was to check how this method affects the development of divergent thinking of managers. The analysis of the criteria for assessing divergent thinking of Torrance, E. (1993) and Guildford, J. (1967) allowed us to make our own list of criteria: originality, flexibility, innovation (development of the idea), dynamism, performance (accuracy). According to these criteria, we assessed divergent thinking of managers in experimental and control groups.

The use of the test of Torrance, E. (1993) for the study of the thinking, we are interested in, was not very informative, since almost all managers had high values. So we used the method of Guildford, J. (1967) of assessing the divergent thinking as well as the method of observers' assessment. To determine the statistical distinctiveness of the results, we used the chi-square test. In Table 2 the criteria of divergent thinking values before the experiment and after it are given.

Table 2. Distinctiveness between groups before and after the experiment

\begin{tabular}{ccc}
\hline \multirow{2}{*}{$\begin{array}{c}\text { The criteria of } \\
\text { divergent } \\
\text { thinking }\end{array}$} & \multicolumn{2}{c}{$\begin{array}{c}\text { Chi-square test } \\
\text { statistic values }\end{array}$} \\
\cline { 2 - 3 } & before & after \\
\hline originality & 0,27 & $\mathbf{2 1 , 5 4}$ \\
\hline flexibility & 0,03 & $\mathbf{1 0 , 2 7}$ \\
\hline innovation & 2,13 & $\mathbf{2 4 , 2 4}$ \\
\hline dynamism & 0,28 & $\mathbf{1 6 , 0 6}$ \\
\hline performance & 1,01 & $\mathbf{1 9 , 5 6}$ \\
\hline
\end{tabular}

Note: Un-bolded style indicates the absence of statistically significant differences between groups (observed value is less than the critical significance level of 0.05), and bold style indicates the presence of statistically significant differences (observed value is greater than the critical value at a significance level of 0.05).

The changes in the development of divergent thinking characteristics as a result of experimental work are marked with the help of the G-criterion of signs, which is used when comparing the measurement data obtained under different conditions on one sample of respondents. G-criterion allows to determine the direction of changes and the degree of their increase. Let's agree that "zero shift" is the absence of changes, "atypical shift" is the increase of 1 point, "typical shift" is the increase of 2 or more points. Eliminating from consideration "zero" shifts, we construct the Table 3. 
Rezanovich, I., Rezanovich, A., Piatkova, M. \& Peredrienko, T. (2020). The method of destructive scenario forecasting for the development of divergent thinking of managers, International Journal of Cognitive Research in Science, Engineering and Education (IJCRSEE), 8(1), 61-67

Table 3. Types of shifts

\begin{tabular}{|c|c|c|c|c|c|}
\hline \multirow[t]{2}{*}{ Types of shift } & \multicolumn{5}{|c|}{ The characteristics of divergent thinking } \\
\hline & Originality & Flexibility & Innovation & Dynamism & Performance \\
\hline \multicolumn{6}{|l|}{ Control group } \\
\hline Typical & 2 & 1 & 0 & 4 & 1 \\
\hline Atypical & 14 & 14 & 11 & 22 & 12 \\
\hline Zero shifts & 59 & 60 & 64 & 49 & 62 \\
\hline Gcr, $p=0.05$ & 4 & 3 & 2 & 8 & 3 \\
\hline Gamp & 14 & 14 & 11 & 22 & 12 \\
\hline Shifts at the significant level of 0.05 & \multicolumn{5}{|c|}{ unreliable } \\
\hline \multicolumn{6}{|l|}{ The experimental group } \\
\hline Typical & 27 & 26 & 22 & 20 & 13 \\
\hline Atypical & 12 & 11 & 9 & 12 & 15 \\
\hline Zero shifts & 38 & 40 & 46 & 35 & 49 \\
\hline Gcr, $p=0.05$ & 13 & 13 & 10 & 10 & 8 \\
\hline Gamp & 12 & 11 & 9 & 12 & 15 \\
\hline Shifts at the significant level of 0.05 & \multicolumn{3}{|c|}{ reliable } & \multicolumn{2}{|c|}{ unreliable } \\
\hline
\end{tabular}

\section{DISCUSSIONS}

As can be seen from the above data, the natural development of divergent thinking components in the control groups was insignificant, and according to the criterion of $G$ signs at the significance level of 0.05 , the shifts are not reliable. In the experimental groups, the three characteristics of divergent thinking shifts are reliable, and in the two remaining groups their number is greater than in the control ones.

Since the educational programs in the experimental and control groups were identical, all the tasks on the content were the same, the classes were conducted by the same teachers, we are convinced that the results obtained are due to the systematic and purposeful application of the method of destructive scenario forecasting in the experimental groups. Consequently, the proposed method can be recognized as effective and recommended for wide practical application for the development of divergent thinking in the system of business education.

\section{CONCLUSIONS}

1. The performed analysis made it possible to fix that divergent thinking is one of the types of human thinking. It is based on the phenomenon of divergence, which is understood as a discrepancy between the sides of the whole. In accordance with this divergent thinking of a manager is defined as a special kind of thinking that allows to generate quickly various management decisions in non-standard situations, taking into account a variety of external and internal factors that affect the event.

2. In determining the characteristics of divergent thinking of a manager the works of E. Torrence and J. Guilford, were used which allowed to highlight its distinctive features: originality, flexibility, innovation(development of ideas), dynamism, performance (Torrance, 1993; Guildford, 1967).

3 . The carried out theoretical analysis and practical work confirmed the effectiveness of the method of destructive scenario forecasting for the development of divergent thinking of managers in the system of business education.

4. The method of destructive forecasting developed by the authors is validated. The technological map of its application reflects the gradual development of divergent thinking of managers.

5. The selected diagnostic methods made it possible to record the past changes in the development of divergent thinking of managers in all experimental groups.

6 . The conducted research does not exhaust all aspects of the identified problem. Further work can be continued in such areas as: the search for new methods of development of divergent thinking; the improvement of the technology of scenario forecasting in group and individual work of managers; the development of methodological support for the application of the method of destructive scenario forecasting for the development of divergent thinking among the specialists in various spheres. 


\section{ACKNOWLEDGEMENTS}

The authors express their gratitude to South Ural State University (national research university), all participants of the research and the editorial team of the International Journal of Cognitive Research in Science, Engineering and Education (IJCRSEE) for making this research possible.

\section{Conflict of interests} interest.

The authors declare no conflict of

\section{REFERENCES}

Acar, S. \& Runco, M. A. (2015). Thinking in multiple directions: Hyperspace categories in divergent thinking. Psychology of Aesthetics, Creativity and the Arts, 9(1), 41-53. https://doi. org/10.1037/a0038501

Ananiev, B. G. (2001). On the problems of modern human science. St. Petersburg: Peter.

Arnheim, R. (2001). What it means to be creative. British Journal of Aesthetics, 41(1), 24-25. https://doi.org/10.1093/bjaesthetics/41.1.24

Bailey, K. G. D., Rembold, L. \& Abreu, Ch. M. (2019). Critical thinking dispositions and skills in the undergraduate research methods classroom. Scholarship of Teaching and Learning in Psychology, https://doi.org/10.1037/st10000158

Brushlinsky, A.V. \& Tikhomirov, O.K. (2013). On the development trends of modern psychology of thinking. National Psychological Journal, 2(10), 10-16. https://doi.org/10.11621 npj.2013.0201

Darwin, Ch. (1998). On the origin of species by means of natural selection, or the preservation of favoured races in the struggle for life? Hertsfordshire: Wordsworth Editions Limited.

Dorfman, L. Ya. (2015). Creative mental field, divergence and variability. Psychological Journal, 36(6), 5-11.

Dweck, C. (2006). Mindset: the new psychology of success. New York: Random House Publishing Group.

Guilford, J. (1967). The nature of human intelligence. New York: McGraw-Hill.

James, M. \& Koller, T. (2000). Emerging markets: features of company valuation. TheMcKinseyQuarterly. № 4, 7-11.

Katrenko, M. V., Nebytova, L. A. \& Sasin, A. A. (2018). Creative thinking of students. Divergence. Bulletin of modern research. 11.7(26), 117-119.

Lee, C. S. \& Therriault, D. J. (2013). The cognitive underpinnings of creative thought: A latent variable analysis exploring the roles of intelligence and working memory in three creative thinking processes. Intelligence, 41(5), 306-320. https://doi.org/10.1016/j. intell.2013.04.008

Lindsay, G., Hull, K. S. \& Thomson, R. F. (2001) Creative and Critical Thinking. St. Petersburg: Peter. http://www.psychology-online.net/ articles/doc-73.html

Lucas, B. \& Hanson, J. (2016) Thinking Like an Engineer: Using Engineering Habits of Mind and
Signature Pedagogies to Redesign Engineering. IJEP, 6(2), 4-13. https://doi.org/10.3991/ijep. v6i2.5366

Maslow, A. H. (1967). A theory of metamotivation: the biological rooting of the value-life. Journal of Humanistic Psychology, 7(2), 93-127. https:// doi.org/10.1177/002216786700700201

Matyushkina, A. A. (2018) Understanding the Problem Situation and its Successful Solution. Izvestia Saratov University. Educational Acmeology. Developmental Psychology, 7(25), 62-67. https://doi.org/10.18500/2304-9790-20187-162-67

Mill, J. St. (2020). The syllogistic and inductive logic system: statement of principles of evidence in connection with research methods. Moscow: Lenand.

Neisser, U. (2004). The development of memory: new questions and old. Developmental Review, 24(1), 154-158. https://doi.org/10.1016/j. dr.2003.09.002.

Piaget, J. (1977). The development of thought: Equilibration of cognitive structures. New York: Viking press. https://doi.org/10.2307/1175382

Riegel, K. F. (1976). The dialectics of human development. American Psychologist, 31(10), 689-700. https://doi.org/10.1037/0003-066X. 31.10 .689

Schneider, A. B. (2007). Experimental psychology. Moscow: Akademicheskiy proekt.

Torrance, E. P. (1993). Understanding Creativity: Where to Start? Psychological Inquiry, 4(3), 232-234. https://doi.org/10.1207/s15327965pli0403_17

Veraksa, N. E. (2019). Dialectical thinking: logic and psychology. Cultural-historical psychology, 15(3), 4-12. https://doi.org/10.17759/ chp. 2019150301

Wallace, A. R. Contributions to the Theory of Natural Selection (2013). Oxford: Oxford University Press. https://doi.org/10.5962/bhl.title.1254

Wertheimer, M. (1945). Productive Thinking. New York: Harper and Brothers, https://doi. org/10.1177/000271624725000171

Wertsch, J. V. (1998). Mind as Action. Oxford University Press. https://doi.org/10.1093/acprof :oso/9780195117530.001.0001 